\title{
Transfer of Land Rights Based on the Data Authorization of Selling in Terms of Authority Giver Died in Pekanbaru
}

\author{
Harmen Syarif; Azmi Fendri; Delfiyanti
}

Notary Masters Study Program, Faculty of Law, Andalas University, Indonesia

http://dx.doi.org/10.18415/ijmmu.v6i4.1071

\begin{abstract}
The transfer of land rights that use the power of attorney to sell as the basis for making the sale and purchase deed by the Land Drafting Official at the Pekanbaru City National Land Agency Office is very much in the interest of the people in Pekanbaru, because in terms of time, procedures, and costs are very practical and efficient. According to the Civil Code, article 1795, the grantor of the power of attorney can be carried out specifically, namely regarding one or more specific interests, or in general, which includes all the interests of the Authorizer. Selling Power is an ability with substitution rights (rights that can be replaced) granted by the owner of the guarantee to the authorized recipient appointed by the owner of the guarantee, to sell to other parties or himself at prices and conditions that are considered both by the guarantee owner and the proxy. The implementation of the transfer of land rights has been regulated in Government Regulation Number 24 of 1997 concerning Land Registration.In practice in the field of the use of the transfer of land rights based on the selling power of attorney, there is no difference as to whether the deed of selling power is still valid or not applicable, because the Office of the National Land Agency in Pekanbaru City only provides conditions for a statement stating that the letter of the authorizer is still alive and the power of attorney deed has never been revoked, which was signed by the power of attorney. In article 1813 to article 1819 the Civil Code has regulated the method of the end of the granting of power. Based on the description above, it will be examined on how the position of the selling power of attorney in the transfer of land rights, how the process of transferring rights to land based on the power of attorney to sell in the event that the authority dies in Pekanbaru, and how the legal consequences of the transfer of land rights based on the power of attorney to sell in the case of the party giving the power of attorney died in Pekanbaru. This research method uses an empirical juridical approach which is a study carried out in terms of applicable laws and regulations and is associated with facts found in the field. The Deed of Sale Authority shall be used as the basis for the process of drafting the Deed of Purchase under the name and at the same time be used as a tool for registering the transfer of land rights at the City of Pekanbaru Land Office. The process of transferring land rights based on the selling power of attorney in the event that the authority dies in Pekanbaru cannot be transferred to the National Land Agency because it is null and void according to articles 1813, 1814, and 1816 Civil Code. As a result of the legal transfer of land rights based on the selling power of attorney where the party who passed away died in Pekanbaru is an act of self-destruction, if you want to continue the transfer of rights must be done first the process of inheritance to the heirs concerned.
\end{abstract}

Keywords: Transfer of Rights to Land; Deed of Sale Authority; Lenders of Death and Pekanbaru 


\section{A. Background}

In the agrarian sphere, land is a part of the earth called the surface of the earth. The land that is meant here does not regulate land in all its aspects, but only regulates one of its aspects, namely land in a juridical sense called rights. Prior to the enactment of the Basic Agrarian Law (UUPA), land law in Indonesia was dualism, meaning that in addition to the recognition of the adoption of customary land law originating from Customary law, land regulations based on Western law ${ }^{1}$ were also recognized.

Land for humans is one of the important factors for life. So that makes humans have a strong desire to control and make the land to continue their lives, it is not surprising that the increasing number of land in this country is subject to dispute, especially in terms of ownership.

Given the importance of land because it can produce natural resources that are very useful for many people, it is necessary to have a legal regulation governed by the government. The 1945 Constitution Article 33 paragraph (3) reads that the Earth and water and the natural resources contained therein are controlled by the state and used for the greatest prosperity of the people. Regarding the transfer of land rights, in article 37 paragraph (1) Government Regulation Number 24 of 1997 concerning land registration states that the transfer of land rights and ownership rights to a unit of flats through the sale and purchase, exchange, grants, income in companies and legal actions other transfer of rights, except transfer of rights through auction can only be registered if proven by a deed made by the authorized PPAT according to the provisions of the applicable laws and regulations.

The intended transfer of rights occurs either because of the sale and purchase, the relinquishment of rights or because of an agreement to impose a debt bond agreement. This obligation is borne by all parties, both by individuals and legal entities which according to land / agrarian law are domiciled as subjects of land rights.

The provision shows that one of the legal actions carried out causes the transfer of land rights and must be registered back in name is a legal act of sale whose act is made in the form of a Deed of Sale (AJB) made by and / or in the presence of the Land Deed Making Officer (PPAT) or better known as AJB behind the name. Then it is used as a tool for registering the transfer of land rights.

The transfer of land rights causes land rights to shift from one person to another. Thus, the transfer is a legal action deliberately done with the aim that the rights to the land move from the transfer to the recipient of the transfer.

The instrument in the transfer of land rights is called the Deed of Sale and Purchase which is an authentic deed as referred to in the provisions of Article 1 PP No. 24 of 1997 and the Regulation of the Head of the National Land Agency / Minister of Agrarian Number 8 of 2013 concerning the Form of PPAT Deed is a deed made by the parties carrying out the relevant legal actions or their proxies (in the case of legal acts of sale and purchase attended by their attorney) before PPAT witnessed by at least 2 (two) witnesses. There are two conditions for buying and selling land ${ }^{2}$ :

\footnotetext{
${ }_{1}^{1}$ Adrian Sutedi, Peralihan Hak Atas Tanah dan Pendaftarannya, Sinar Grafika, Jakarta, 2006, p. 1.

${ }^{2}$ Ibid., p. 77.
} 


\section{Material Requirements}

Material conditions will determine the validity of buying and selling land, among others, as follows:

a. The buyer has the right to buy the land in question.

The point is that the buyer as the recipient of the right must meet the requirements to own the land he will buy.

b. The seller has the right to sell the relevant land.

Those who have the right to sell a plot of land are, of course, legitimate holders of the rights to the land called the owner. If the owner of a piece of land is only one person, then he has the right to sell the land himself. However, if the owner of the land is two people, those who have the right to sell the land are the two people together.

c. Land rights concerned may be traded and are not in dispute.

Regarding what land rights can be traded, it has been determined in the UUPA, namely ownership rights (article 20), cultivation rights (article 28), building rights (Article 35), usage rights (article 41)

\section{Formal Requirements}

After all material requirements have been fulfilled, the PPAT (Land Deed Making Officer) will make the sale and purchase deed. Before the deed of sale and purchase is made PPAT, it is required for the parties to submit the required documents, namely seller data such as a photocopy of Resident Identity Card and Family Card (husband and wife), Marriage Certificate if married, Original land certificate, Land Tax and Buildings (Tax Return Notification (SPPT) and Proof of Payment), buyer data is only a photocopy of Resident Identity Card, Marriage Certificate, and Family Card.

In addition to the Sale and Purchase Deed, the transfer of land rights can also be carried out on the basis of a Power of Attorney to Sell in the form of an authentic deed made by a Notary. The buyer can later sell to another party without the need for legal assistance from the seller or in this case it is used to sell to himself the buyer for the purpose of transferring the rights to the land and building.

The transfer of land rights to the Purchase Deed of transfer of name is carried out on behalf of the buyer himself, then in making the first-party and second-party sale and purchase deeds are the recipient of the power of attorney based on the said Sales Authority. If the buyer is not the party that receives the power of attorney (the power of attorney sells it again to another party) then the first party is the power of attorney from the Selling Power of Attorney and the second party is the party of the buyer (the other party who buys on the land sold).

In the practice of making sale and purchase certificates, sometimes it often happens to use the power to sell. In principle, the function of the power of attorney to sell is because the seller cannot be present in buying and selling of his land so that it gives the power to sell to other parties appointed by the seller himself.

Power of Attorney or Lastgeving is an agreement (overenkomst) where there is a party giving power or power (macht) to another person (lasthebber) to act or carry out legal actions on behalf of the power of authority (lastgever). In connection with the concept of power of attorney, the arrangement can be found in Article 1792 of the Civil Code (hereinafter the Civil Code) relating to the granting of power, 
which determines as "an agreement of a person as an authorizer with another person as the recipient of the power to carry out an act / action to be able to "On behalf of" the authorizer ".

Thus, based on the provisions of Article 1792 of the Civil Code, the nature of the power of attorney is "to represent" or "to represent", "to represent" here means the authority to represent the recipient to administer and carry out the interests of the authorizer. The meaning of the word "on behalf of" the meaning of this article is the recipient of the power to act or act on behalf of the authorizer ${ }^{3}$.

In the implementation of the transfer of land rights based on the power to sell, in practice it is usually only related to the time of the power of attorney, i.e. whether the power of attorney has passed from 1 (one) year or not, as permitted by the National Land Agency. Of course this is very risky. However, obstacles that arise if the transfer of land rights based on the power to sell are the giver of death and the transfer of land rights have not been done so that the problem of transition cannot occur due to the cancellation of the power to sell.

In the case of granting power of attorney to sell a parcel of land / building, then as stipulated in Article 1796 of the Civil Code, such power of attorney must be made specifically and expressly stated in the act. Specific understanding and firm words here certainly do not only concern the right to sell an object of land / building on behalf of the seller, but also concerning who the buyer is and what the agreed price is, all of which must be contained in the deed of power to sell.

In practice, the granting of the power of attorney to sell as above has caused the Power of Attorney to be used as the basis for the process of making a Purchase Deed behind the name and at the same time a means of registering the transfer of land rights at the Land Office at the place where the land is located. In other words, registration of the transfer of rights is found based on the deed of Sell Power of attorney without following the deed of the Purchase Agreement (PPJB). Meanwhile, the Selling Authority referred to is not an absolute power that is prohibited by law or that land and buildings as objects in the deed of Selling Authority have been paid in full. Problems arising from the existence of the power of attorney to sell that are used in the registration of the transfer of Land Rights are not found in the regulation in PP. 24 of 1997 concerning Land Registration. So the implementation of the registration of the transfer of land rights as well as obstacles and any factors that can cancel the transfer of land rights is very important to study, thus the researcher takes the title "Transfer of Land Rights Based on the Deed of Selling Authority in the case of a Power of Attorney in Pekanbaru"

\section{B. Problem Formulation}

Based on the background description of the problem, a research problem can be formulated with the title "How is the transfer of land rights based on the deed of selling power in the event that the giver dies in Pekanbaru?"

\footnotetext{
${ }^{3}$ M.Yahya Harahap, Segi-Segi Hukum Perjanjian, Alumni, Bandung, 1986, p. 306.
} 


\section{Discussion}

The process of transferring rights over land based on the power of attorney to sell in the event that the authorizer dies in Pekanbaru.

The basis of the authority of the Notary Public General who is authorized to make an authentic deed as the authority granted by the law and the transfer of land rights made in the presence of the land deed official can be done on the basis of the power to sell related to the preliminary agreement, namely the binding agreement of sale buy made by a notary public.

The binding purchase agreement was born as a result of not fulfilling the requirements as determined by the laws and regulations relating to the sale and purchase of land, which in turn will hamper the completion of the sale and purchase transaction. The requirements referred to those born due to existing laws or regulations arose from the agreement of the parties who will enter into the agreement.

In general, the requirements that often arise are requirements that are born from the agreement of the parties who will carry out buying and selling transactions. These requirements can be varied, for example because the full purchase price has not been paid in full, or the land title certificate is being finalized under the name of the authorized agency, while the prospective seller and prospective buyer have agreed to make a sale and purchase transaction.

With these conditions hampered, it could result in rejection by the Land Deed Makers Officer in making the sale and purchase deed. To anticipate the problem, the parties can make an agreement to maintain the agreement that has happened before, to keep the agreement carried out properly while the requested conditions can be fulfilled, the parties can make an initial agreement in an agreement that is finally known as binding sale and purchase agreement.

The power of attorney to sell is one form of special power of attorney, which is made following the making of a binding agreement to buy and sell land rights before a notary.

The obstacles faced in the transfer of land rights based on the power of attorney to sell are:

1. The time of the power of attorney is that the power to sell is only given 1 year by the National Land Agency

2. The power to sell is only allowed to be used in one transfer of land rights to the same object

3. Obstacles that arise in the transfer of land rights based on the power to sell are the death giver and the transfer of land rights have not been made so that the problem of transition cannot occur due to the cancellation of the power to sell ${ }^{4}$.

The position and role of land rights in Indonesian society is very important. Because of the importance of the position and role of land it often causes problems. To create prosperity and welfare of the people as desired by the Indonesian people as stipulated in article 33 paragraph 3 of the 1945 Constitution which reads Earth, water and natural resources contained therein are controlled by the State and used for the greatest prosperity of the people, then the problems relating to the use, ownership, authority and transfer of land rights require special attention in the laws and regulations, so on September 24, 1960 came out the legislation on land, known as Law No. 5 of 1960 concerning Basic Regulations on Agrarian Principles or better known as the Basic Agrarian Law (UUPA).

\footnotetext{
${ }^{4}$ The results of an interview with Riri Liestia, as a Notary / PPAT in Pekanbaru, on 4 July 2019.
} 
With the aim of providing legal certainty in the land sector, because prior to the issuance of the Basic Agrarian Law (UUPA) in Indonesia, two legal systems in the land sector were applied, namely land law based on customary law (hak ulayat) and land law based on western law found in BW (Burgerlijk Wetboek / Civil Code). One of the methods used to meet the need for land is through buying and selling. Buying and selling is not new in our society, because the practice of buying and selling has long been done since ancient times. The buying and selling process is usually done with an agreement or agreement between the parties concerned. The sale and purchase agreement was born at the time of reaching agreement on the goods and prices.

Once the two parties have agreed on the goods and the price, a legitimate sale and purchase agreement is born. Buying and selling with objects of land rights, also carried out with agreements to further provide legal certainty, because land rights are included in the object of the agreement specifically regulated in the applicable laws and regulations, where every legal action concerning land rights is bound or must follow the provisions set out in the legislation.

It means that the party who will carry out legal actions concerning land rights, must obey the legal rules governing or relating to the regulation of land rights. With the existence of a special regulation regarding the transfer of land rights, it sometimes creates difficulties for the community.

People who know about the power of sale often transfer their rights to their land by carrying out the signing of the deed of sale based on the deed of selling power. Based on information from interviews with several Notaries / PPAT Pekanbaru City, there are several conditions that must be met in the process of transferring land rights based on the deed of power of attorney to sign the sale and purchase deed in Pekanbaru, including:

1. Copy of deed of selling authority from Notary / PPAT

2. Identity Card and Family Card from the relevant parties

3. Taxpayer and Seller Taxpayer Identification Number

4. Marriage papers of the parties

5. Building Land Tax for the current year

6. Proof of payment of Building Land Tax

7. Payment of Fees for the Acquisition of Rights to Land and Buildings (BPHTB)

8. Payment of Tax Payment (SSP)

9. Tax payment statements from the parties

10. Statement of paying tax from PPAT

\section{Declared soil statement}

12. The statement is still alive from the recipient of the power of attorney stating that the power of attorney is still alive and states that his deed of attorney has never been revoked.

\section{Fill out the Attachment Form 13}




\section{Introduction to PPAT Requests}

15. Deed of sale and purchase

16. Original certificates

After all the requirements are completed and the deed of sale and purchase are signed before the PPAT by the parties, witnesses, and the PPAT is then registered with the Pekanbaru City National Land Agency with the following process:

1. Take the queue number at the queue counter at the Pekanbaru City National Land Agency Office.

2. Waiting for the queue in the queue waiting room at the Office of the National Land Agency of Pekanbaru city until the queue number is called by the ticket window clerk.

3. Go to the counter according to its purpose, namely the counter where the deed of sale and purchase process is based on the deed of sales authorization, then submit the file to the ticket window clerk. The ticket clerk immediately checks the file that we submitted, if the file is declared complete, the file is immediately entered by the entry clerk to make payment of the file.

4. Next, wait for the window clerk to call the name of our transition file after the entry is completed by the entry clerk.

5. After that the ticket window clerk calls our name, the next step we make payment of the file that has been entered to the payment counter, the method of payment is non-cash, that is, using an ATM card on the Electronic Data Capture (EDC) machine, by chance the EDC machine provided at the Agency Office Pekanbaru City National Land at that time, namely at EDC Bank Rakyat Indonesia, EDC Bank Mandiri, EDC Bank Negara Indonesia, if there is no ATM card, then we can pay cash at banks that have cooperation with payment of Non-Tax State Revenue (PNBP), by bringing evidence of deposit orders given from the Office of the National Land Agency to the Bank that we are aiming for.

6. After making payment of the file at the payment window we get proof of payment and receipt of the file from the payment window clerk.

7. Next we are waiting for the process of transferring land rights based on the power of attorney selling with the PPAT sale and purchase deed at the National Land Office of Pekanbaru City with Operational Standards for Transfer of Rights service, which is 5 (five) working days, counted after the payment of the said file.

8. After five working days we return to the Office of the Pekanbaru National Land Agency by bringing evidence of receipt of the file given by officers from the Office of the National Land Agency of the City of Pekanbaru, to retrieve the results of recording the transfer of rights in the certificate that we have at the File Collection Counter completed.

The process of transferring land rights is based on the selling power of attorney where the authority of the death of the authority, if it is not known at the receipt window of the document that the authorizer died at the Office of the National Land Agency of the City of Pekanbaru, the process of transfer of land rights continues because the Pekanbaru National Land Agency requests A statement letter is still alive, stating that the authorizer at the time of signing the sale and purchase deed of the authorizer is still alive and states that the sales authorization deed made at the Notary / PPAT concerned is still valid and has never been revoked. 
As long as no party declares the death of the authorizer, the deed of sale and purchase can still be continued. But if it is known that one of the parties has died, either the person giving the power of attorney or the person receiving the power of attorney who has died, the registration of the transfer of land rights is denied or returned to the PPAT concerned by the Office of the National Land Agency of Pekanbaru City 5 .

\section{Conclusions}

In answer to the main problem, the following authors state the conclusions and suggestions from the results of research and complete discussion is as follows:

The process of implementing the transfer of land rights based on the power of attorney to sell where the power of attorney dies in Pekanbaru is able to be processed if no one party informs that the authority has died, but if it is known that the person giving the power of attorney has died then the deed of attorney will automatically fail or null and void according to the legal rules contained in article 1813 of the Civil Code. Therefore before anyone dies they must immediately transfer the rights to the land, because the deed of attorney is still valid.

\section{References}

Books

Adrian Sutedi, Peralihan Hak Atas Tanah dan Pendaftarannya, Sinar Grafika, Jakarta, 2006.

Kartini Muljadi dan Gunawan Widjaja, Hak-Hak Atas Tanah, Kencana, Jakarta, 2005.

L \& J A Law Firm, Kiat dan Prosedur Mengurus Dokumen Tanah dan Bangunan, Nera Pustaka, Jakarta, 2013.

M. Yahya Harahap, Segi-Segi Hukum Perjanjian, Alumni, Bandung, 1986.

M.Solly Lubis, Filsafat dan Ilmu Penelitian, Mandar Maju, Bandung, 1994.

Purwahid Patrik, Dasar-Dasar Hukum Perikatan, Mandar Maju, Bandung, 1994.

Penelitian Pengantar Hukum, UI Press, Jakarta, 1996.

Ronny Hanitijo Soemitro, Metodologi Penelitian Hukum dan Jurimetri, Ghalia Indonesia, Jakarta, 2009.

Saleh Adiwinata, Pengertian Hukum Adat Menurut Undang-Undang Pokok Agraria Alumni, Cetakan ke 2, Bandung, 1980.

Sudikno Mertokusumo, Teori Hukum, Cahaya Atma Pustaka, Yogyakarta, 2012.

\footnotetext{
${ }^{5}$ The results of an interview with Nasep Vandi sulistyo, as the Official of the Pekanbaru City National Land Agency Office,
} on July 10, 2019 
Soedikno Mertukusumo I, Hukum dan Politik Agraria, Krunika, Universitas Terbuka, Jakarta, 1988.

Subekti R, Pokok-Pokok Hukum Perdata, Jakarta: Indonesia,1985.

Urip Santoso, Pendaftaran dan Peralihan Hak Atas Tanah, Kencana, Jakarta, 2004.

Wantjik Saleh K, Hak Anda Atas Tanah, Ghalia Indonesia, Jakarta, 1977.

Wirjono Prodjodikoro, Asas-Asas Hukum Perjanjian, Sumur Bandung, Bandung,1973.

Wirjono Prodjodikoro, Hukum Perdata Tentang Persetujuan-Persetujuan Tertentu, Sumur Bandung, Bandung, 1981.

Legislation

Peraturan Pemerintah Nomor 37 Tahun 1998 tentang Pejabat Pembuat Akta Tanah.

Peraturam Menteri Dalam Negeri Nomor 14 tahun 1982, tentang larangan Kuasa Mutlak.

Undang-Undang Nomor 30 Tahun 2004 tentang Jabatan Notaris.

Kitab Undang-Undang Hukum Perdata.

Undang-Undang Nomor 5 tahun 1960 tentang Peraturan Dasar Pokok-pokok Agraria.

Peraturan Pemerintah nomor 24 tahun 1997 tentang Pendaftaran Tanah .

Internet

Https://denyelfaruq.wordpress.com/peralihan-hak-atas-tanah-melalui-jual-beli/.

Wilayah geografis-Pekanbaru.go.id Pemerintah Kota Pekanbaru.

Sejarah -Pekanbaru.go.id Pemerintah Kota Pekanbaru.

\section{Copyrights}

Copyright for this article is retained by the author(s), with first publication rights granted to the journal. This is an open-access article distributed under the terms and conditions of the Creative Commons Attribution license (http://creativecommons.org/licenses/by/4.0/). 